\title{
Pengaruh Pendidikan Di Daerah Terpencil
}

leni karlina

lenikarlina252@gmail.com

\begin{abstract}
ABSTRAK
rakyat di indonesia atau bangsa indonesia ini belum memenuhi kualitas pendidikan yang yang di inginkan atau di harapkan di bandingkan dengan kualitas negara yang memiliki terbaik di dunia seperti pendidikan yang maju di finlandia indonesia di bisa di kategorikan sangat jauh tertinnggal dengan indonesia hal ini dapat di lihat dari presentasi pesererta didik yang menjadi tolak ukur pendidikan, dalam meningkatkan mutu pendidikan supervisi pendidikan memiliki peranan yang sangat penting dan sangat di butuhkan dalam pengembangan mutu pendidikan. dunia yang serba pendidikan saat ini atau dunia berilmu pengetahuan membuat orang-orang bersaing secara berpendidikan.
\end{abstract}

\section{A. latar belakanng}

Kualitas pendidikan di Indonesia saat ini sangat memprihatinkan. Ini dibuktikan antara lain dengan data UNESCO (2000) tentang peringkat Indeks Pengembangan Manusia (Human Development Index), yaitu komposisi dari peringkat pencapaian pendidikan, kesehatan, dan penghasilan per kepala yang menunjukkan, bahwa indeks pengembangan manusia Indonesia makin menurun. di daerah terpencil pendidikan masih belum menyeluruh atau masih belum merata di karenakan jarak dan anggota tenaga pendidikan tidak memadai dan sarana pendidiikan untuk wilayah tercepencil tidak memadai itulah yang menyebabkan pendidikan di daerah terpencil tidak merasakan pendidikan yang baik atau yang semestinya, sehingga tidak ada fasilitas yang cukup memadai untuk menunjang kemajuan proses belajar mengajar mereka lakukan, dan juga tenaga didik yang mengajar dengan ilmu yang seadanya. Sebagaimana yang dikemukakan oleh sabandi (Sabandi, 2013) bahwa kualitas pembelajaran guru relatif masih rendah. Guru masih merupakan sumber belajar utama bagi siswa. . semua kondisi ini dan masalah rill yang ada di daerah terpncil menjadi masalah bersama yang menggugah rasa nasionalisme kita untuk mengatasinya. dalam 
perpektif ini rasa nasionalisme yang kita berbentuk melalui kesadaran universal dari seluruh komponen bangsa untuk bersama-sama memberi perioritas bagi percepatan pelayanan pendidikan dan mutu pendidikan di daerah tterpencil tersebut.

\section{B. pembahasan}

pendidikan merupakan wadah penting yang menjadi titik krusial pembentukan mental, spritual, sekaligus inteleksualitas bagi generasi bangsa. rendahnya kualitas dan mutu pendidikan di derah terpencil di sebabkan adanya permasalahan-permasalahan di dunia pendidikan. permasalahan pendidikan merupakan suatu kendala yang menghalangi tercapainya tujuan pendidikan. pendidikan yang di lakukan pemerintahan pusat di daerah tidak menjangkau daerah-daerah terpencil. sehingga hal ini akan mengakibatkan mayoritas penduduk indonesia yang dalam usia sekolah tidak dapat mengenyam pelaksanaan pendidikan yang sempurna sebagimana yang di harapkan. pendidikan dapat terjadi dengan baik atau yang di harapkan di daerah terpencil apabila menyediakan fasilitas sarana belajar bagi setiap lapisan masyarakat yang wajib mendapatkan pendidikan. pemberian sarana dan prasarana yang cukup dan tenaga pendidik yang mengajar yang mempunyai ilmu pengetahuan dan mutu pendidikan yang baik. mutu sama halnya dengan memiliki kualitas dan bobot. jadi pendidikan yang bermutu yaitu pelaksanaan pendidikan yang dapat menghasilkan tenaga profesional sesuai dengan kebutuhan negara dan bangsa pada saat ini. salah satu bagian penting yang berperan dalam kemajuan pendidikan di daerrah terpencil adalah guru, kesejahteraan guru berdampak pada mutu pengajaran yang ada. sekarang ini masih banyak guru yang engabdikan dirinya di daerah terpencil di bayar dengan upah yang kurang layak bahkan sama sekali tidak mendapat upah. meskipun banyak anggapan profesi guru merupakan profesi yang enak namun banyak guru di indonesia khususnya di daerah terpencil yang masih menerima gaji yang tidak sesuai apalagi guru honorer atau guru bantu. akibatnya para guru kurang bersemangat dalam mengajar. datang dan pulang sekolah seenaknya. ada juga yang menjalani profesi sampingan selain menjadi seorang guru.

\section{C. kesimpulan}

realitas yang ada di bangsa kita tidak perlu di berikan ruang khusus dan perhatian dari pemerintah pusat hingga ke daerah, juga seluruh lapisan masyrakat. karena 
bagaimana pun anak bangsa indonesia di seluruh pelosok di daerah- daerah yang terpencil berhak mendaptkan pendidikan yang layak. pendidikan di daerah terpencil memang masih sangat rendah. hal hal yang menyebabkan rendahnya kualitas dan mutu pendidikan di daerah terpencil di antaranya, kurangnya pemerataan pendidikan, masih rendahnya kesejahteraan guru, rendahnya prestasi siwa, dan tidak adanya sarana dan prasarana yang memadai. hal tersebut hanya bisa di atasi dengan kerja sama antara pemerintahan dengan seluruh lapisan masyarakat untuk meningkatkan kualitas mutu pendidikan di daerah terpencil.

\section{D. referensi}

ahmad,sabandi 2013/11/1 supervisi ppendidikan nasioanal guru berkelanjutan

H.fitriyadi-jurnal pendidikan teknologi dan kejuruan,2013-joornl.uny.ac.id

M.rohman jurnal kependidikan dan kemasyarakatan,2016-jurnal,iainponogoro.ac.sid

Sabandi, A. (2013). Supervisi Pendidikan Untuk Pengembangan Profesionalitas Guru Supervisi Pendidikan Untuk Pengembangan Profesionalitas Guru Berkelanjutan Oleh:

Pedagogi, Junal IImiah IImu Pendidikan, XVII(2), 1-9. Retrieved from http://ejournal.unp.ac.id/index.php/pedagogi/article/view/4275/3345 